\title{
The Myth of Human Origin for Harmonization of Life and Indonesianness
}

\author{
Mu'jizah $^{1}$, Erlis Nur Mujiningsih ${ }^{2}$, Purwaningsih $^{3}$ \\ \{mujizah555@gmail.com\} \\ Center for Research and Development and Training, Ministry of Religious Affairs ${ }^{1}$, Agency for \\ Development and Cultivation Language, Ministry of Education and Culture ${ }^{23}$
}

\begin{abstract}
Indonesia is known as a multiethnic and multicultural country. Many tribes live in Indonesia, such as Javanese, Sundanese, Malay, Achenese, Toraja, and Banjar. They have thought was expressed in folktale, especially the myth of human origins. The myth called aetiologias and including the oldest story. This oldest story would be interesting to study relate it to the Indonesianness concept. This paper will discuss how myth of the human origin was formed by society in the past for harmonization of life and how the story consist a concept related to Indonesianness in the present? This study used a structural approach and comparative study. From the results of this study was found the diversity and similar of the motif from the story. From the comparison of the stories concluded that Indonesianness had been built since ancient times through the same concept of myth of the human origin. A kingdom or country in the past was always led by special humans which was marriages between the underworld and the upperworld. This marriage became a common thread that connected the origin of human found in the stories in many ethnic groups in Indonesia.
\end{abstract}

Keywords: Objection; Tax Dispute; Appeals; Tax Lawsuit

\section{Introduction}

A great nation is characterized by the excellence of his literary work. Literature used as a milestone because it is the work of a specific communication that reflects the mindset of the people. Indonesia as a country that was formed since 1928 it has various ethnic groups. The diversity and unity of ethnic is needed to find a concept what is Indonesianness? This concept can be form of an ideology that is in politics and culture. One of the most prominent of culturses is literature. In the past, Indonesia had a wealth of literature formed of manuscripts and oral literature, such as folklore.

This work is owned by many ethnic groups in Indonesia, one of which is the Malay tribe. This ethnic use the Malay language to write literary works. This Malay language later developed became the Indonesian language. Apart from the Malays there are also other tribes that have manuscripts and oral literature that use regional languages, such as the Javanese, the Sundanese and the Sasak, and the Toraja tribes. These literary works are expressed in their respective regional languages.

These literary works spread widely with the same motives and themes. One of them is about the birth of human origins. These motives can be used to search for the Indonesianness concept, a concept based on literary diversity. If Indonesia consists of various ethnic groups with their 
own cultures, then where is Indonesianness? This problem attracts the attention of researchers to discuss oral literature, especially folklore by examining the diversity and unity of the myth about the motifs of human origin stories to search of Indonesianness.

Myth the origin of man according to called aetiologis. The story is classified as an oldest story [1] This myth in a literary history is the early part of the myth that explains origin of the king. Main story tells a origin of human derived from motif of marriage unusual. There is mankind who married with special person. In Hikayat Banjar, man married with the daughter of derived from bamboo sewer (Buluh Betung). Hikayat Raja Pasai tells people who also married the daughter of bamboo, and Sejarah Melayu describing man came from of Islamic hero, there is Iskandar Zulkarnain. Hikayat Bangsa Jin dan Segala Dewa-Dewa from Bima derived man from God, and Hikayat Aceh tells the story there is a man married to an angel.

Story about motif of human marriage to angel is too folklore tells it. This type of story is almost owned by many tribes in Indonesia. Popular stories with the motifs is "Jaka Tarub" from Java "Raja Pala" from Bali. The story with this motif is also in the "Malem Dewa" from Gayo, "Indra Zamrud" from Bima, "Telaga Bidadari" from South Kalimantan, and "Tujuh Bidadari" from Ternate. In addition, there are also folklore entitled "Polo Padang", "Manusia Pertama dari Sangir Talaud", "Marakarma and Siraiman", and "Oheo".

This paper discusses the problem of how the myth of human origins was formed by society in the past to create a harmonious life and how does this story reflect the concept of Indonesianness in the present? The purpose of this research is to find the concept of Indonesianness through folklore with the motive of human origins which is widespread in Indonesia. This concept is very important for understanding culture through stories. This understanding is expected to create the harmonization of life of the diversity Indonesian people.

\section{Research Methods}

In the study of the myth of human origin for harmonization of life and Indonesianness is used the qualitative method. This approach is used to explore these ideas. For this reason, this research used a structural method and comparative studies. The first step is inventory of the data. The second is identify the motives in the stories. Motive comes up as a concept that is dominant through deliberate repetition. These motives have appeared through significant phrases [2]. According to [3], motives were the driving elements to the next events in the plot of the story that led to the climax and the end of the story. The types of motives in story has been listed in Thompson (1958) and Propp (1977).

They register of many motive stories in the world. His works are Motive Index of Literature. Analysis of the structure with a model motive has been done also by Alan Dundes. The method of analysis structural Alan Dundes is based on the method of analysis structural developed by [4]. Motifeme of Dundes might be likened to function of Propp. [5] function according to Propp (1977: 25) can be found in a story by seeing the sequence of events and the sequence of events had functions show basic morphology of story.

Relating to the study of the story with above model, Humme once examined the mouse deer motif in "Javaansche Sprookjs" [6]. Brandes conducted research on the mouse deer motif in Dwerghert-verhalen uit den Archipel, Javaanche De Serat Saloka Darma [7]. [8] was ever studied of research with story of motive nymphs. His article was published in titled "Figures Nymphs to the Kite in of Folktales in Indonesia". In this regard, Danandjaja (1984: 53) claim that motive is one of the constituents a story (narratives elements). Elements that can be thing 
(such a stick will), animals remarkable (horses that can be speaking), a concept (prohibition or taboo), a deed (test dexterity), fraud to a figure (a giant or to a deity), type specified person (the pandir, the kabayan), or of the nature of a definite structure (e.g. repetition based on the sacred as the number three and seven).

\section{Results and Discussion}

Myth of origins of human in traditional literature, particularly manuscripts, found in genre of literary history. As we know, the literary history was consisting in two elements. There is elements of myth and historical elements. This mythical element that displays the origin story which shows the genealogy of the kings of holy beings. The existence of an element of myth in the literary history of this also led to the emergence of controversy. There are experts who allege literary history can be used as a source of history and some are saying it cannot be used as a source of history. Origin myths in human marriage with a god or an angel has spoken also by Ras (1966) in The Hikayat Banjar. Nymth (often called angel) are characters in literature. KBBI (2008) nymph meant as beautiful and elegant woman who comes from heaven. In Danandjaja (1984) the story with such a model called the girl motif pelican (swan maiden), which figures to be human bird incarnation.

In literary history, the origins of human motifs associated with the wedding motif unusual (unusual married). Unusual marriage took place with extraordinary human or holy beings, such as nymph and women emerging from bamboo or foam. In the story, usually angel left her husband (fairy mistress leaves man) with a variety of stories. The second motive is found in some manuscripts. In Hikayat Aceh [9] King Muhammad Shah find a reed marvellous. In reed he found a nymph form bamboo named Putri Buluh Betung. Later the king married the woman. From marriage were born Sultan Shah and her daughter Sapiah, who became ancestors Acehnese people.

Someday, eventually he left the king because the prince repeals the rome below the chin daughter goddess of the senses, princess surprised and dead. In addition, there is also the Shah he plays close in swimming pools and when her eyes wide was showering seven nymth. He took proved to be true. In addition, there is also the King Shah Mohammad playing near the pool and in the pool, he saw seven nymphs bathing. He took the clothes fly the youngest daughter named Princess Medini Candra and married her. From this marriage was born Sulaiman Shah and Princess Arkiah. One day King Mohammed scolds his two sons and daughter are not willing to Medini Candra scolded her children, and she left with the fly clothes into the air.

In Hikayat Bandjar [10] also told Lambu Mangkurat who meet a daughter Putri Junjung Buih that arises from froth. This daughter is just wanting to marry a child asceticism. One day he met with the son of a King Majapahit named Raden Putra, a son of Majapahit. This kid found the King Majapahit of out from the sun. Before marriage Raden Putra has got a crown derived from the sky. On this marriage is born the royal descendants Banjarmasin. In Hikayat Raja Pasai [11] told the King Muhammad find the princess in bamboo named Putri Betung and the King Ahmad find a son in above gadjah named Merah Gadjah. Putri Betung and Merah Gadjah married and have two sons. They are Merah Silu dan Merah Hasum. Merah Silu has power in Perlak with title of a King Malikus Seleh, one who founds Pasai.

In Sejarah Melayu [12], the myths associated with the descendants of Sultan Iskandar Zulkarnain. The story is told also that the origin of the Malay Rulers was also of a cow Wan Empuk and Wan Malini who spew foam. It bubbles forth from man named Tun Sri Buana 
married with young girl street named Wan Sendari. This king wandered to many places and dominate the place, among them Bintan and Singapore or Temasek.

Motives of human origins in manuscripts are slightly different with a myth in folklore. [13] Motives is found in many stories. In 2010, Mu'jizah and her tim in Language center with consultants Pudentia , Ikram, and Rusyana registered about 27 stories from several areas. In the research was found many stories with nymth motive. There are "Jaka Tarub" from Java, "Malem Dewa" from Gayo , Aceh , "Polo Padang" from Toraja, "Gumasalangi" from Sangir Talaud, and "Telaga Bidadari" from South Kalimantan [13]

Compared with the literary history of the manuscript, motif in folklore is more complex. Based on Motif Index of Folk Literature [14] in the folklore found nine motive, namely (1) angel down shower (F265: fairy bathing); (2) theft of clothes fly (H1151.22: task stealing clothing of beautiful witch); (3) man married to an angel (T110: unussual marriage); (4) The prohibition husband cannot see the work in the kitchen (F348.8: taboo: mortal for whom fairy works must not watch him at work); (5) magical objects received from the angel / wife (D81210: magic object received from angel (angel helper), D815.8: magic object received from wife); (6) when breaking a promise, not a grain of rice into the rice before it can be processed (F348.0.1: fairy gift disappears or is turned to something worthless when the taboo is broken); (7) the origin of cooking rice (1415: origin of cooking (cooking of rice)); (8) the angel left her husband when the ban violated (F302.6: fairy mistress leaves man when he breaks taboo); (9) restrictions must be adhered to if visiting fairyland (F378: taboos connected with a trip to the fairy land).

That side of motives, there are four motive dominant, which are (1) nymphs down bathroom, ( 2 ) of a marriage unusual in a human manner married nymphs, (3) theft his fly, and ( 4 ) nymphs leave her husband when ban violated. On the other hand, a small proportion of story fair motive same to the fourth motives above, but a series of the scenes varied. Motives nymphs down bathroom in the story is effort to arrange two worlds, the world of kayangan and the earth. Nymth down from kayangan aims to bathroom and enjoy natural beauty the earth and more specifically gardens and coolness water pool.

In some stories, the source of water is not only well, but rivers, ponds and wells. Generally, nymth coming down it was seven persons, but there are also three peraon likes the story of "Polo Padang", nine persons in "Manusia Pertama in the Talaud Islands", and ten persons in "Meraksamana and Siraiman". The tools used to be down to earth in the form of a rainbow, scarf, or clothe fly. In the motive of theft, theft of clothes fly actors are men who are fascinated by the beauty and elegance of the Angels and men that want to marry her. The desire to marry Angel was achieved because an angel loses shirt of flight and he kept his shirt or scarf stolen in the granary. In some stories is stored in trees of betung (bamboo). Most of the story's clothes stolen were clothes youngest daughter, just the story of Papua daughter marry the eldest daughter.

Motif breach of promise found in almost all stories. In a marriage between the nymth and man, there is a taboo that should not be violated by the husband who is married to a nymth, which opened the pot or cooking utensil when cooking is done sprite. However, human curiosity is greater so that the ban violated. The husband opened the lid of the pot or cookware. Only in the story "Oheo" nymth taboo to wash dirt and his story "Polo Padang" nymth forbids him to retract his hair even though only a piece.

In a comparison of fairy tales seen some changes. The changes occur due to adjustments in the cultural context. Motif story nymph or daughter of heaven is the one who became the first queen or king and ancestor of the inhabitants of the earth. The similarity of cultural property signifies the unity of the basic cultural and historical owned by residents of the Malays in 
Indonesia so that there are similarities in the fundamental cultural values in the society to strengthen the bond of unity.

Motif angel coming from heaven, or another world indicates that people believe in the existence of supernatural world beyond human reach but is closely related to the human world and influence it. This close relationship related and are represented by a second motive, namely marriage between creatures of the earth and the other-worldly beings (unusual marriage). The marriage will bring happiness to man. In all the stories, happiness realized with ease childbirth and got a meal, is the availability of paddy rice directly, without having to go through the process is complicated and exhausting, that pounding, winnowing, washing, and cooking.

Interesting variation of the angel motif is the motif of testing of the main character "Gumansalangi" in the story of the Sangihe Talaud that initially appear as a man who behaves evil, but ultimately happiness. A daughter of diseased descended from the sky as a trial if the man has a sense of humanity and sacrifice that deserve the gift of the gods. Marriage 'unusual' here still present, but as a cover or a happy ending, and the problem of broken promises nothing. Here the motive daughter of heaven and marriage between heaven and earth creatures have been created as a support Gumansalangi story is actually a story of ethnic origin Sangihe recognized from Mindanao

In the dissolution reasons of affection between husband and wife there are also some interesting variations. Tells the story of Jake Tarub ruse used by him to memperisteri Goddess Nawangwulan. Between the two there is also a promise that should not be violated. Violation of this promise with regard to basic food that depends completely on local ethnography. In the story "Jaka Tarub" pledge was violated is open rice dishes that will be cooked rice. By itself this motif does not comply with the regional ethnography main meal instead of rice. With the owners of literary creativity of the people this is overcome by replacing it with another motif detail, namely breach agreed previously taboo, including the pronunciation of certain words, and perform certain acts.

The basic values that also appear in the stories as rules to be adhered together is the firmness of the promises must be respected: if violated will inevitably bring disastrous mala. The relationship established between husband and wife, which essentially brings happiness, gone because the promise is violated by the desire to know who is not in place. All happiness, children, wives and ease of life lost due to act reckless. Here is evident also ignorant of human nature: it has been given the gift of excessive but cannot appreciate it. A variety of motives-ban violations are taboo motif as already stated above.

Cultural values are fundamental and should be embraced by the people for the benefit of himself is the maintenance of the environment, which consists of plants and animals. When human beings in distress, natural sekitarnyalah which will bring relief. When Mamanua, one of the characters in the story of North Sulawesi looking for his wife who had left him, rattan, tall trees and flying fish help him so that he found his wife, children. In the story of Toraja, whose help is eel, wind king, the king of finches, and other animals that provide assistance. In this test motif depicted that way to repent after breaking a promise, it is very heavy, but with unyielding willpower and Polo Padang Mamanua finally rediscovering happiness with their wives and children.

Belief in a higher power, and fidelity to the promise of reckoning for defaulting, persistence in the pursuit of happiness, upkeep and maintenance of the flora and fauna in the community are values that are taught and should underpin a society that has such stories. The values are felt to this day are still valid and should be held by modern humans.

In the spread across the region covered by the motive stories nymphs have been many changes that are adjustments to the ethnographic area as well as population penyambutnya. 
Some motifs arise or affixed as a creative adjustment in a different environment. The motifs that characterize that characterize the relationship with certain regions. In areas that are not familiar with rice as a main meal, the motive of the rice or rice by itself will be lost because they do not correspond to the natural state of the area concerned.

Oral literature is not in a space that is impermeable influence, even he is very sensitive to movement and flow experienced by supporters, so there is no folk literature that looks certain and sustainable. A motive may change due to the time of life has shifted, as was the case with his wife and child motif search conducted by key figures in a number of versions. In this version of South Aceh, Malim Dewa is looking for his wife in heaven, there to teach the children the Koran and playing the flute. Here the story has been infiltrated by Islamic elements.

In some versions of the conjugal covenant between a ban or taboos, which was then hit by the husband with the same result, namely the return of the wife into a fairyland. Marriage motif variation between the creatures of the earth with creatures of the heavens that are likely to be part of the myth of the first man on the island of Sangihe display changes into a snake magic that brought the two main characters of the family across the sea to the island of Mindanao Kotabatu in Sangihe. It can be seen that the main motive consistency, creativity and cultural influences local folklore form a mosaic that shows the unity that is full of variety, which reflect the culture of the Indonesian nation.

The culture is not without significance in society. They believe that their ancestors, including the king made him a leader not arbitrary. Genealogy describing genealogical works to melegitmasi power that the king is chosen. The choice fell on the belief that human society was formed by natural selection in human nature itself, nature can lower or upper world, heaven.

\section{Conclusion}

From the above discussion it was concluded a few things. The myth of human origins in Indonesia is very diverse. In the myth that is found in traditional Malay literature and other literary treasures. In the manuscript, the myth of the origin of Malay visible diversity, ranging from the marriage of man with a buluh betung (bamboo) man of froth, the hero of Islam, and an angel. Men with angel marriage is more common in folklore. Motif in the script is shorter than in folklore. The motive was just there at the beginning, while the motif in folklore is displayed intact. Diversity and uniformity motif origins reflect the value of the culture of Indonesian society.

That value has an important position in public life. The basic value is that the rules must be adhered to along and promises must be kept. When broken promise will surely bring calamity. Belief in a higher power down only in the selection, the leader. These forces can legitimize their rule as king. In addition, persistence in the pursuit of happiness, maintain and preserve the flora and fauna in the community are values that are taught and should underlie community life story owner.

From the comparison of this stories, the Indonesian concept is reflected. This concept has apparently been built since ancient times through myths with the same motive about human origins. The story told that a kingdom or country in the past was always led by special humans who were born from a marriage between the underworld and the upper world. This marriage is the link that unites the human origins found in the stories of various ethnic groups in Indonesia. 


\section{References}

[1] Liaw Yock Fang, Sejarah Kesusastraan Melayu Klassik Sejarah Kesusastraan Melayu Klassik. Jakarta: Erlangga., 1979.

[2] Abrams, The Mirror and the Lamp Romantic Theory and the Critical Tradition. Oxford: Oxpord Unversity Press., 1971.

[3] S. Sulastin, Hikayat Hangtuah: Analisa Struktur dan Fungsi. Yogyakarta: Gadjah Mada University Press., 1983.

[4] V. Propp, Morphology of the Folktale. University of Texas Press, 1977.

[5] J. Danandjaja, Folklor Indonesia: Ilmu Gosip, Dongeng, dan lain-lain. Jakarta: PT Grafiti Pers., 1984.

[6] H. C. Humme, “'Javaansche Sprookjes' 'Dongeng-Dongeng Jawa'.," Land-en Volkenkd. van Ned., p. $83-111,1883$.

[7] J. L. A. Brandes, ““'Dongeng Kancil dari Nusantara, Dongeng Jawa, Serat Saloka Darma",” KITLV XLVI, vol. 1, pp. 73--91, 1903.

[8] S. W. Rudjiati, "“Tokoh Bidadari dengan Baju Layang-Layang dalam Cerita-Cerita Rakyat di Indonesia'.," 1982.

[9] T. Iskandar, “'De Hikajat Atjeh,” VKI, vol. 26, 1958.

[10] J. Ras, Hikayat Bandjar: A Study in Malay Historiography. The Hague: Martinus Nijhoff., 1966.

[11] R. Jones, Hikayat Raja Pasai. Petaling Jaya: Fajar Bakti, 1987.

[12] S. Ahmad, Sulalatus Salatin (Sejarah Melayu). Kuala Lumpur: Dewan Bahasa dan Pustaka., 1984.

[13] Mu'jizah, Pemetaan Cerita Rakyat Di Indonesia: Motif Bidadari. Jakarta: Pusat Bahasa., 2010.

[14] S. Thompson, Motif-Index of Folk Literature Volume 1. New Enlarged and Revised Edition. Indiana University Press. Bloomington. Indiana, 1958. 